\title{
Epicatechin and Procyanidin B2 in the Stem and Root bark of Sterculia tragacantha Lindl (Sterculiaceae)
}

Orisakeye OT* and Olugbade TA

Department of Pharmaceutical Chemistry, Obafemi Awolowo University, Ile-Ife, Nigeria

\begin{abstract}
This study investigated the anti-oxidant activities of both the stem and root bark of Sterculia tragacantha, isolated its active compounds and characterised the isolated compounds.

The plant parts and the isolated compounds were screened for anti-oxidant activity by Thin Layer Chromatography technique using 2, 2-diphenyl-1-dipicrylhydrazyl (DPPH). Extracts were fractionated using Medium Pressure Liquid Chromatography guided by bioautography to isolate active substances. The isolated compounds were characterised using Nuclear Magnetic Resonance spectroscopy and by comparison of spectroscopic data with literature values.

The results revealed that the crude extracts and two compounds possess strong anti-oxidant activity and antibacterial activity. Epicatechin was isolated from both the stem and the root bark while Procyanidin $B_{2}, C_{4}-C_{8}$ dimer of epicatechin, was isolated from the stem bark.

In conclusion, this study suggests that the crude extracts, epicatechin and procyanidin B2 which demonstrated strong anti-oxidant activities can provide efficient antioxidant protection by complementary mechanism, such as free radical scavenging and metal ions reduction.
\end{abstract}

Keywords: Sterculia tragacantha Lindl; Epicatechin; Procyanidin; $\mathrm{B}_{2}$; DPPH; Antioxidant activity

\section{Introduction}

The family sterculiaceae is mostly found in the tropical and warm areas but a few are found in the temperate areas [1]. Sterculia tragacantha (sterculiaceae) is one of the 150 species of the 60 genera of the genus Sterculia $[1,2]$. Sterculia species have been extensively used in traditional medicine in the various countries where they are found.

In the Solomon Islands, Sterculia lepidoto-stellata is used to treat common cold. Sterculia lychnophora is used as tea in Cambodia. Sterculia macrophylla is used as an aphrodisiac in Java. In Australia, Sterculia quadrifolia is used as peanut tree. Sterculia rubiginosa is used as fruit diet in Guiana. Sterculia scaphigera, in Thailand, is used to treat fever, Sterculia shillinglawii is used to treat fever, and action is tonic [3].

Sterculia tragacantha has been employed in the treatment of boils, diarrhoea, dyspepsia, fever, gonorrhea, snake bite, syphilis, tapeworm in Burkina Faso, Cameroon, Ghana, Guinea, Ivory coast, Nigeria and Sierra Leone, action is anodyne and vermifuge [4,5] . Also infusions of the leaves of Sterculia tracagantha are used to treat malaria [6]. In India, Sterculia urens is used to treat fistula, rhagades, with the indigenous use which is known as santal [5]. Sterculia villosa is used as an antidote (Lizard) to treat fistula, night fever. Both C. acuminata and C. nitida are used as nerve stimulants, diuretics and odiotonics [7]. Cola nitida is specially used for pains [8].

The only literature report [9] on the Chemistry of Sterculia tragacantha is the fatty acid composition of the seeds. Phytochemical groups have also been reported to contain phenolics, peptides and cyclo-peptides [10]. Sterculia tragacantha leaves have been reported to show anti-ulcer, anticholinergic, antispasmodic and smooth muscle relaxant effects [9].

Epicatechin the major component isolated from both the root and stem barks, in this research work, is known in literature to possess antioxidant, anti-ulcer and anti-inflammatory [8]. The biological properties of procyanidins have also been extensively reviewed to possess anti-oxidant properties, antitumor activities and antimicrobial activity [11-13]. So also plant parts of Sterculia tragacantha have been reported to possess strong antibacterial properties [10].

The present study obtained the crude extracts of the stem and root barks of Sterculia tragacantha, determines their antioxidant properties, anti-bacterial properties isolate and characterise isolated compounds.

\section{Experimental and Results}

\section{Plant materials and general experimental details}

Fresh plant parts (stem and root bark) of Sterculia tragacantha were collected along Road 1, OAU campus. The plants were authenticated by comparison with herbarium sample at the herbarium of Dept of Botany, OAU, Ile-Ife. All organic solvents were redistilled before use. The observed rotation was obtained using Digital Polarimeter Polax2L, ATAGO CO., LTD. USA. Isolation and purification process were monitored by a DPPH guided bioautography method.

\section{Extraction and Isolation}

Compound 1 from the stem bark: Fresh stem bark was collected, airdried $(930 \mathrm{~g})$, milled and extracted with methanol at room temperature for $48 \mathrm{~h}$ and filtered. The filtrate was concentrated to dryness in vacuo to yield crude extract Sterculia tragacantha $(20 \mathrm{~g})$.

The crude extract (20g) was dissolved in 5\% methanol in ethylacetate. This was passed through silica gel by vacuum chromatography. Further elution with the methanol and ethylacetate yielded $4 \mathrm{UV}$ active spots

*Corresponding author: Orisakeye OT, Department of Pharmaceutical Chemistry Obafemi Awolowo University, Ile-Ife, Nigeria, Tel: +234 8037400826; E-mail: tolukeye@yahoo.com or jumokeye@gmail.com

Received December 13, 2013; Accepted February 26, 2014; Published February 28, 2014

Citation: Orisakeye OT, Olugbade TA (2014) Epicatechin and Procyanidin B2 in the Stem and Root bark of Sterculia tragacantha Lindl (Sterculiaceae). Med chem 4: 334-337. doi:10.4172/2161-0444.1000161

Copyright: (C) 2014 Orisakeye OT, et al. This is an open-access article distributed under the terms of the Creative Commons Attribution License, which permits unrestricted use, distribution, and reproduction in any medium, provided the original author and source are credited. 
fractions (A,B,C,D). A and B were bulked together (E) (400 mg) because they showed similar tlc profile (two yellow sports before spraying and three pink sport after spraying with vanillin sulphuric acid and heating at $\mathrm{R}_{\mathrm{f}}=0.6,0.3,0.2$ respectively. $\mathrm{C}$ and $\mathrm{D}$ could not be processed further because of the quantity.

Fraction E (400 mg) was subjected to Accelerated Gradient Chromatography and the constituents eluted on silica gel using hexanedichloromethane-methanol solvent mixture $(100 \mathrm{ml})$ in gradient.

The active spots fractions yielded (Stem bark Sterculia tragacantha) Sst $001(72 \mathrm{mg})$, known as compound 1 , and sst002 $(74 \mathrm{mg})$. They were obtained after combining fractions with similar TLC characteristics.

Sst $002(74 \mathrm{mg})$ was further purified by Preparative Thin Layer Chromatography using silica plate of $1 \mathrm{~mm}$ thickness and developed in dichloromethane: methanol (7:3) to give a major UV detectable band. This band was scrapped and eluted with dichloromethane: methanol $(1: 1)$ and the resulting eluate was concentrated in vacuo to yield 3sst $002(57 \mathrm{mg})$ known as compound 2.

Compound 1 was obtained as a pink reacting substance on silica (vanillin- $\mathrm{H}_{2} \mathrm{SO}_{4}$ spray) with $\mathrm{R}_{\mathrm{f}}=0.5$. It was $\mathrm{UV}$ active and had immediate anti-oxidant property.

Compound 2 was also obtained as a deep red reacting substance on silica (vanillin $-\mathrm{H}_{2} \mathrm{SO}_{4}$ spray) with $\mathrm{R}_{\mathrm{f}}=0.22$.

Compound 3 from the root bark: Fresh root bark was collected, (wet weight $=950 \mathrm{~g}$ ) and extracted with methanol at room temperature for $48 \mathrm{hr}$ and filtered. The filtrate was concentrated to dryness in vacuo to yield crude $S$. tragacantha (26 g). The crude extract ( $26 \mathrm{~g})$ was subjected to AGC and the constituents eluted on silica gel using hexanedichloromethane-methanol in gradient. The test tubes collected were analyzed by TLC using solvent systems $30 \%$ methanol (reverse phase).

Tube fractions showing similar tlc characteristics were bulked together and concentrated in vacuo to yield fractions STRB/RP/0.42 (Sterculia tragacantha root bark) at $\mathrm{R}_{\mathrm{f}}=0.42$ (eluted in tubes 2830) $\left(15 \mathrm{mg}\right.$ ) and $S T R B / R P / 0.31$ a $R_{f}=0.31$ (eluted in tubes $35-40$ ) (10mg). STRB4/RP/0.42 could not be processed further because of the quantity and it was a mixture of dimer of epicatechin. STRB was further performed on reverse phase column purification. R.P 0.31 was obtained as compound 3 .

Compound 3 was obtained as a pink colour after spraying with vanillin sulphuric spraying reagent which is characteristics of $R_{f}=0.5$. It was UV active compound with immediate antioxidant property and strongly phenolic. This pure product of compound 3 was obtained as a pink reacting substance. The NMR data of compound 3 isolated from the root bark is identical with compound 1 isolated from the stem bark. Therefore, compound 3 was identified as epicatechin (Figure 1).

\section{Antioxidant test}

A solution of the test material in method was spotted on the tlc plate and developed using a suitable solvent system. This was sprayed with 2,2-diphenyl-1-dipicrylhydrazyl (DPPH) reagent. The chromatogram was exposed to daylight until the purple to yellow within the first fifteen minutes after spraying were recorded as positive results (i.e possess antioxidant activity). The result of the screening of the different plant materials are summarized in plate 1.

Preparation of 2,2-diphenyl-1-dipicrylhydrazyl (DPPH) solution: $(0.3 \mathrm{mM}) \mathrm{DPPH}(12 \mathrm{mg})$ was dissolved in $\mathrm{MeOH}$ in volumetric flask $(100 \mathrm{ml})$ and kept in the dark until use.

\section{Antimicrobial screening}

The agar diffusion (cup plate) method was used for this examination. Molten and cooled agar $60 \mathrm{ml}\left(45^{\circ} \mathrm{C}\right)$ were separately inoculated with the nutrient broth culture of the test organisms $(0.6 \mathrm{ml})$ and mixed thoroughly. The inoculated medium was then carefully poured into sterile Petri dishes (24 cm Petri dish) and allowed to set. Thereafter, cups ( $9 \mathrm{~mm}$ diameter) were aseptically bored into the solid nutrient agar using a sterile cork borer. The test solutions $100 \mu \mathrm{L}$ each were then introduced into each of the cups ensuring that no spillage occurred. Also the same volume of the standard antimicrobial agent and the solvent were introduced into some of the cups to act as positive and negative controls respectively. The plates were left at room temperature for 2 hours to allow for diffusion into the medium and thereafter incubated face upwards at $37^{\circ} \mathrm{C}$ for 24 hours. Sample was tested in duplicate and the diameters of zone of inhibition were measured to the nearest millimeter using a transparent ruler.

The result of the antimicrobial assays show that the crude extract of Sterculia tragacantha root bark and stem bark in $80 \mathrm{mg} / \mathrm{ml}$ in $50 \%$ methanol were active against Staphylococcus aureus showing the zone of inhibition to be $5 \mathrm{~mm}$ and Bacillus subtilis showing the zone of inhibition to be $6 \mathrm{~mm}$ and $7 \mathrm{~mm}$ respectively.<smiles>Oc1cc(O)c2c(c1)O[C@H](c1ccc(O)c(O)c1)[C@H](O)C2</smiles>

Epicatechin

Figure 1: Structure of Epicatechin

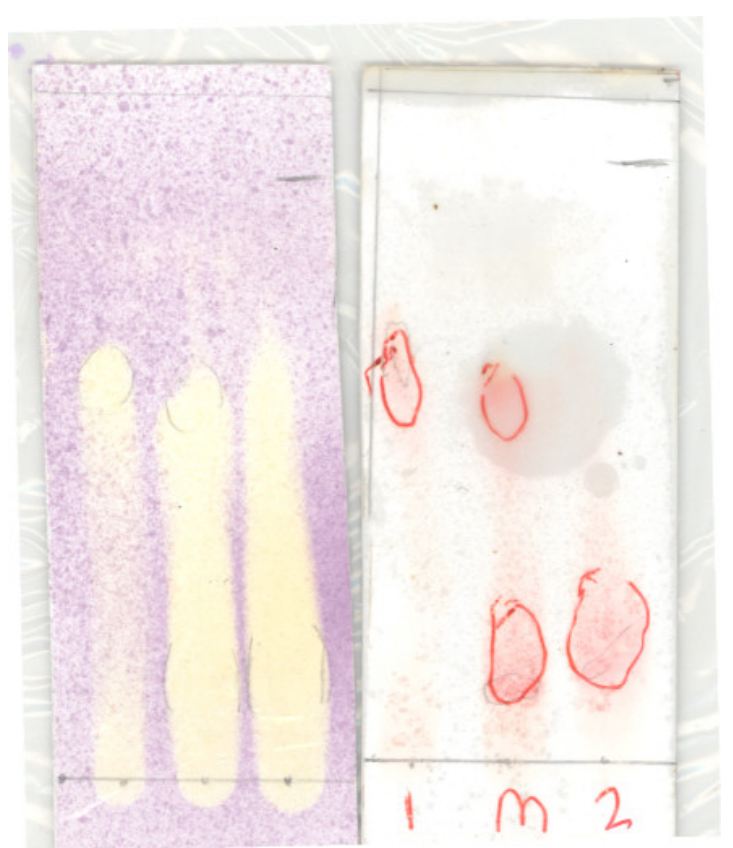

Plate 1: Antioxidant screening and tlc profile of sst001 and 3sst002 (DCM:MeOH) Antioxidant properties (A) of (sst001)(1), (3sst002)(2), and a mixture $(m)$ compared with vanillin- $\mathrm{H}_{2} \mathrm{SO}_{4}$ sprayed plate $(B)$. 


\section{Bioautography technique for anti-microbial screening}

The method involved an overlay of inoculated agar medium on developed silica gel tlc glass plates followed by incubation at $37^{\circ} \mathrm{C}$ for $24 \mathrm{~h}$. After incubation and revelation with tetrazolium salt, inhibition zones are visible as decolorized spots against purple background (Plate 2).

\section{Discussion}

\section{Characterisation of sst001 as Epicatechin}

The Sst 001 was a brown powder. It gave a deep pink colour with vanillin-sulphuric after heating with $\mathrm{R}_{\mathrm{f}}=0.63$ in dichloromethane: methanol (30:10) silica. It showed antioxidant activity with DPPH. It showed strong reaction with ferric chloride indicating the presence of phenolic. Interestingly, both the crude extracts and the two compounds isolated showed anti microbial activity.

Sst 001 was unequivocally identified as Epicatechin (2,3 cis configuration) rather than its C-3 epimer, Catechin (2,3 trans configuration), by virtue of the weak coupling between $\mathrm{H}-3$ and $\mathrm{H}-2$, $(\mathrm{H}-2, \delta 4.87, \mathrm{~s})$ indicating cis disposition as detailed in Table 1. C-2 of $\delta 78.8$ confirms epicatechin as the C-2 of Catechin resonates at 82.0 [2]. Interestingly the alcoholic $\mathrm{OH}$ at position 3 showed coupling with $\mathrm{H}-3$ $(\mathrm{J} 5.6 \mathrm{~Hz})$ in the acetone spectra.

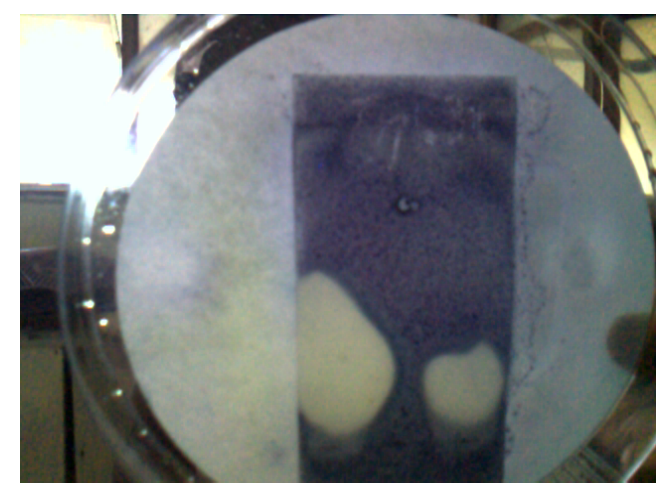

Plate 2: Bioautography technique of Epicatechin and Procyanidin B2 isolated from S.tragacantha root and stem bark using Bacillus substillis as test organism.

\begin{tabular}{|l|c|c|c|}
\hline$\Delta \mathbf{C}$ & DEPT & H & Assignment \\
\hline 156.94 & $\mathrm{C}$ & - & \\
\hline 156.92 & $\mathrm{C}$ & - & \\
\hline 156.53 & $\mathrm{C}$ & - & \\
\hline 144.75 & $\mathrm{C}$ & - & \\
\hline 144.64 & $\mathrm{C}$ & - & \\
\hline 131.6 & $\mathrm{C}$ & - & \\
\hline 118.69 & $\mathrm{CH}$ & $6.84, \mathrm{dd}, \mathrm{J} 1.7,8.1 \mathrm{~Hz}$ & $\mathrm{H}-6{ }^{\prime}$ \\
\hline 114.83 & $\mathrm{CH}$ & $6.78, \mathrm{~d}, \mathrm{~J} 8.1 \mathrm{~Hz}$ & $\mathrm{H}-5$ \\
\hline 114.61 & $\mathrm{CH}$ & $7.05, \mathrm{~d}, \mathrm{~J} 1.7 \mathrm{~Hz}$ & $\mathrm{H}-2 \mathbf{\prime}^{\prime}$ \\
\hline 99.13 & $\mathrm{C}$ & - & \\
\hline 95.51 & $\mathrm{CH}$ & $6.02, \mathrm{~d}, \mathrm{~J} 2.2 \mathrm{~Hz}$ & $\mathrm{H}-6$ \\
\hline 95.03 & $\mathrm{CH}$ & $5.91, \mathrm{~d}, \mathrm{~J} 2.2 \mathrm{~Hz}$ & $\mathrm{H}-8$ \\
\hline 78.76 & $\mathrm{CH}$ & $4.87 \mathrm{brs}$ & $\mathrm{H}-2$ \\
\hline 66.28 & $\mathrm{CH}$ & $4.20, \mathrm{~m}$ & $\mathrm{H}-3$ \\
\hline 28.33 & $\mathrm{CH} 2$ & $2,72, \mathrm{dd}, \mathrm{J} 3.3,16.7 \mathrm{~Hz}$ & $\mathrm{H}-4$ \\
\hline
\end{tabular}

*Assignment aided by COSY, DEPT and HETCOR experiments

ठ3.63 (d, J5.6Hz 3-OH), $\delta 7.9$ (brs,2xOH), $\delta 8.0$ (brs, OH), $\delta 8.2$ (brs, OH)

Table 1: NMR Data of sst001*<smiles></smiles>

Procyanidin B2

Figure 2: Structure of Procyanidin B2.

\section{Characterisation of 3sst002 as Procyanidin B2}

The 3sst002 gave a deep red colour after spraying with vanillin sulphuric spraying reagent which is characteristics of Procyanidin ( a dimer of epicatechin) with $\mathrm{R}_{\mathrm{f}}=0.22$ in dichloromethane: methanol (25:5) on silica (Figure 2).

The observed strong reactions with ferric chloride indicate the presence of phenolic function. It also showed strong reaction with DPPH indicating strong antioxidant activity.

The ${ }^{1} \mathrm{H}-\mathrm{NMR}$ spectrum of 3 sst002 showed two broad singlet signals at $\delta 4.98(1 \mathrm{H})$ and $5.11(1 \mathrm{H})$, which are ascribable to $\mathrm{H}-2$ of flavan-3-ol frameworks.

These observations were also consistent with the ${ }^{13} \mathrm{C}$-NMR data which clearly showed the presence of two flavan-3-ol $\mathrm{C}_{2}$ atoms $(\delta 76.2$ and 78.5). The absence of downfield signal at about $\delta 82$ indicates the absence of catechin and confirms the two flavan-3-ol residues as epicatechin. In order to clarify the points of the interflavanoid linkages, the appearance of an aliphatic $\mathrm{CH}(\delta 4.74)$ and one $\mathrm{CH}_{2}(\delta 2.73,2.93)$ indicate the involvement of a $\mathrm{C}-4$ position in the interflavanoid linkage. The position of linkage on the second flavanol ring is evidently on the aromatic ring A with only three $\mathrm{H}$ bearing Carbon signals for the C- 6 and C- 8 positions $(\delta 95.6,95.1,96.4)$, the fourth signal being a quaternary $\mathrm{C}(\delta 106.3)$.

The interflavanol linkage is thus $\mathrm{C} 4 / \mathrm{C} 8$ (Procyanidin B2) or C4/ C6 (Procyanidin B5). However, Procyanidins B2 and B5 are practically indistinguishable by NMR chemical shift values (Table 2).

The difference in the optical rotation of $\mathrm{B} 2[\alpha]=29.2^{\circ}[8]$ and $\mathrm{B} 5[\alpha]$ $=+102^{\circ}[4]$ as reported in literature is significant. The observed rotation of 3 sst002 in the present study was $+29.4^{\circ}$. Compound 2 was therefore unequivocally established as Procyanidin B2.

\section{Conclusion}

The crude extracts of S.tragacantha showed anti-oxidant property in the DPPH model and anti-microbial activity.

Epicatechin was isolated for the first time from the root bark as well as the stem bark of S.tragacantha. Procyanidin B2 was isolated for the first time from the stem bark of the plant.

The presence of epicatechin and procyanidin B2 in the plant is significant in view of the known important anti-oxidant activities of the two compounds in the inhibition of peroxidation of lipid in human body and to extend the shelf life of food.

This study suggests that the crude extracts and the isolated 
Citation: Orisakeye OT, Olugbade TA (2014) Epicatechin and Procyanidin B2 in the Stem and Root bark of Sterculia tragacantha Lindl (Sterculiaceae). Med chem 4: 334-337. doi:10.4172/2161-0444.1000161

\begin{tabular}{|c|c|c|c|c|c|c|c|c|c|}
\hline \multirow[b]{2}{*}{ Position } & \multicolumn{3}{|c|}{$1 \mathrm{H} \mathrm{nmr}$} & \multicolumn{6}{|c|}{$13 \mathrm{C} \mathrm{nmr}$} \\
\hline & $\begin{array}{l}\text { B2 } \\
{[13]}\end{array}$ & $\begin{array}{l}\text { 3sst002 } \\
\text { (acetone } \\
\text { +D2O) }\end{array}$ & $\begin{array}{l}\text { B5 } \\
{[13]}\end{array}$ & $\begin{array}{l}\text { B2 } \\
{[14]}\end{array}$ & $\begin{array}{l}\text { B5 } \\
{[14]}\end{array}$ & $\begin{array}{l}\text { 3sst002 } \\
\text { (acetone } \\
\text { +D2O) }\end{array}$ & $\begin{array}{l}\text { B2 } \\
{[15]}\end{array}$ & B5[15] & $\begin{array}{l}\text { B2 } \\
{[16] \text { (CD3OD) }}\end{array}$ \\
\hline 2 & $\begin{array}{l}\text { (U) } 4.99 \\
\text { (L) } 4.92\end{array}$ & $\begin{array}{l}\text { (U) } 5.111 \\
\text { (L) } 4.979\end{array}$ & $\begin{array}{l}\text { (U) } 4.90 \\
\text { (L) } 4.77\end{array}$ & $\begin{array}{l}\text { (U)76.6, } \\
\text { (L)79.1 }\end{array}$ & $\begin{array}{l}\text { (U)76.6, } \\
\text { (L)78.9 }\end{array}$ & $\begin{array}{l}\text { (U)76.2, } \\
\text { (L)78.5 }\end{array}$ & $\begin{array}{l}\text { (U)76.55, } \\
\text { (L)78.91 }\end{array}$ & $\begin{array}{l}\text { (U)76.69, } \\
\text { (L)78.98 }\end{array}$ & $\begin{array}{l}\text { (U) } 77.9, \\
\text { (L)80.6 }\end{array}$ \\
\hline 3 & $\begin{array}{l}\text { (U)3.85 } \\
\text { (L)4.29 }\end{array}$ & $\begin{array}{l}\text { (U) } 4.010 \\
\text { (L) } 4.312\end{array}$ & $\begin{array}{l}\text { (U) } 3.99 \\
\text { (L) } 4.13\end{array}$ & $\begin{array}{l}\text { (U)72.8, } \\
\text { (L)66.2 }\end{array}$ & $\begin{array}{l}\text { (U)72.1, } \\
\text { (L)66.6 }\end{array}$ & $\begin{array}{l}\text { (U)72.2, } \\
\text { (L)65.7 }\end{array}$ & $\begin{array}{l}\text { (U)72.56, } \\
\text { (L)65.99 }\end{array}$ & $\begin{array}{l}\text { (U)71.73, } \\
\text { (L)66.49 }\end{array}$ & $\begin{array}{l}\text { (U)74.3, } \\
\text { (L)67.8 }\end{array}$ \\
\hline 4 & $\begin{array}{l}\text { (U) } 4.63 \\
\text { (L)2.83,2.69 }\end{array}$ & $\begin{array}{l}\text { (U)4.741, } \\
\text { (L)2.731,2.925 }\end{array}$ & $\begin{array}{l}\text { (U)4.54 } \\
\text { (L)2.585,2.745 }\end{array}$ & $\begin{array}{l}\text { (U)36.7, } \\
\text { (L)29.1 }\end{array}$ & $\begin{array}{l}\text { (U) } 37.0 \\
\text { (L)28.9 }\end{array}$ & $\begin{array}{l}\text { (U)36.2, } \\
\text { (L)28.3 }\end{array}$ & $\begin{array}{l}\text { (U)36.60, } \\
\text { (L)28.92 }\end{array}$ & $\begin{array}{l}\text { (U)37.03, } \\
\text { (L)29.04 }\end{array}$ & $\begin{array}{l}\text { (U) } 37.7 \\
\text { (L)30.5 }\end{array}$ \\
\hline $\begin{array}{l}5,7,8 \mathrm{a} \\
(U, L)\end{array}$ & & & & & & $157.6,156.8,155.2$ & $\begin{array}{l}155.6,157.3 \\
157.9\end{array}$ & $\begin{array}{l}\text { 154.73,155.50, } \\
157.44\end{array}$ & $\begin{array}{l}\text { 158.5,159.1, } \\
157.2\end{array}$ \\
\hline 6 & $\begin{array}{l}\text { 5.91, } \\
5.92(U, \mathrm{~L})\end{array}$ & 6.02 & 6.02 & $\begin{array}{l}\text { (U)96.5, } \\
\text { (L)97.4 }\end{array}$ & $\begin{array}{l}\text { (U)96.9, } \\
\text { (L)108.6 }\end{array}$ & $\begin{array}{l}\text { (U)96.4, } \\
\text { (L)95.1 }\end{array}$ & $\begin{array}{l}\text { (U)95.48, } \\
\text { (L)96.03 }\end{array}$ & $\begin{array}{l}\text { (U)95.49, } \\
\text { (L) } 96.11\end{array}$ & $\begin{array}{l}\text { (U) } 97.1, \\
\text { (L)98.0 }\end{array}$ \\
\hline 8 & 5.98 & & $6.06,6.04(U, \mathrm{~L})$ & $\begin{array}{l}\text { (U)96.0 } \\
\text { (L)107.7 }\end{array}$ & $\begin{array}{l}\text { (U)96.0, } \\
\text { (L) } 96.9\end{array}$ & $\begin{array}{l}\text { (U)95.6, } \\
\text { (L)106.3 }\end{array}$ & 96.81, & 96.32, & $\begin{array}{l}\text { (U)98.1, } \\
\text { (L)108.1 }\end{array}$ \\
\hline $4 a$ & & & & & & 99.8 & 100.22 & 100.18 & 101.0,102.1(U,L) \\
\hline $1^{\prime}$ & & & & & & $\begin{array}{l}\text { (U)131.5, } \\
\text { (L)130.98 }\end{array}$ & $\begin{array}{l}\text { (U)131.41, } \\
\text { (L)131.90 }\end{array}$ & $\begin{array}{l}\text { (U)131.72, } \\
\text { (L)131.62, }\end{array}$ & $\begin{array}{l}\text { (U)132.8, } \\
\text { (L)133.4 }\end{array}$ \\
\hline $2^{\prime}$ & 6.92 & $6.94(\mathrm{U}, \mathrm{L})$ & $6.95,6.99(\mathrm{U}, \mathrm{L})$ & & & $\begin{array}{l}\text { (U)114.6, } \\
\text { (L)114.3 }\end{array}$ & $\begin{array}{l}\text { (U)115.05, } \\
\text { (L)114.77 }\end{array}$ & $\begin{array}{l}\text { (U)115.01, } \\
\text { (L)115.38 }\end{array}$ & $\begin{array}{l}\text { (U)116.1, } \\
\text { (L)116.7 }\end{array}$ \\
\hline $\begin{array}{l}3^{\prime}, 4^{\prime} \\
(U, L)\end{array}$ & & & & & & $144.8,144.6,144.4$ & $\begin{array}{l}144.76,144.95 \\
145.14\end{array}$ & $\begin{array}{l}145.0,145.12 \\
145.20\end{array}$ & 146.5,146.4, 155.2, \\
\hline $5^{\prime}$ & $\begin{array}{l}\text { 6.68, } \\
6.70(U, \mathrm{~L})\end{array}$ & $6.72(U, L)$ & $6.74,6.75(\mathrm{U}, \mathrm{L})$ & & & $\begin{array}{l}\text { (U)114.8, } \\
\text { (L)115.0 }\end{array}$ & $\begin{array}{l}\text { (U)115.35, } \\
\text { (L)115.48 }\end{array}$ & $\begin{array}{l}\text { (U)115.01, } \\
\text { (L)115.38 }\end{array}$ & $\begin{array}{l}\text { (U)116.1, } \\
\text { (L)116.7 }\end{array}$ \\
\hline $6^{\prime}$ & $\begin{array}{l}6.87 \\
6.58(U, \mathrm{~L})\end{array}$ & 6.66(U,L) & $6.64,6.78(\mathrm{U}, \mathrm{L})$ & & & $\begin{array}{l}\text { (U)118.5, } \\
\text { (L)118.3 }\end{array}$ & 118.95 & $\begin{array}{l}\text { (U)118.98, } \\
\text { (L)118.90 }\end{array}$ & \\
\hline
\end{tabular}

Table 2: NMR Data of B2 and B5

compounds of both the stem and root bark of the plant are rich sources of antioxidant potential. S.tragacantha crude extract might also be useful in the treatment of any damage tissue cause by oxidation agents in human body and it can also serve as a natural antioxidant in food industry instead of synthetic preservative antioxidant.

The presence of anti-microbial activity of the two compounds explains its use in the treatment of boils and diarrhoea.

\section{Acknowledgement}

Thanks to Mr. Adaramola (Retired), of the Department of Botany, Obafemi Awolowo University, Ile-Ife, Nigeria. Support provided by the International Programme in the Chemical Sciences (IPICS), Uppsala, Sweden through the Nig. 01 project is duly acknowledged.

\section{References}

1. Foo LY, Karchesy JJ (1988) Procyanidin dimers and trimers from Douglas Fir inner bark. Phytochemistry, 28: 1743-1747.

2. Haslam E (1998) Practical Polyphenolic form structure to molecular recognition and physiological action. Cambridge University Press, Cambridge. 1st ed 1-89.

3. Irvine FR (1961) Woody Plants of Ghana. With special reference to their uses. Oxford University Press, London. 508- 575.

4. Dennis F, Odamtten GT, Agbovie T, Amponsah K,Crentsil OR (2002) Conservation and sustainable use of medicinal plants in Ghana. Afr J Infect Dis $38: 215$

5. Johnson T, Wyatt R (2004) Herbage plants.

6. Coles M (1981) Study of medicinal plants in Gloucester village. PhD Thesis, Department of Botany, University of Sierra Leone. (unpublished).
7. Dalziel JM (1956) The useful plants of West Africa. Crown Agents for overseas Government and Administration; London. 217.

8. Lans C (2007) Comparison of plants used for skin and stomach problems in Trinidad and Tobago with Asian ethnomedicine. J EthnobiolEthnomed 3: 3.

9. Gaydou ME, Ramanoelina ARP, Rasoarahona JRE, Combres A (1993) Fatty acid composition of Sterculia seeds and oils from Madagascar. J Agric Food Chem 41:64-66.

10. Orisakeye OT,Olugbade TA (2012) Studies on antimicrobial activity and phytochemical analysis of the plant SterculiatragacanthaLindl. Middle-East Journal of Scientific Research 11: 924-927.

11. Bagchi D1, Garg A, Krohn RL, Bagchi M, Tran MX, et al. (1997) Oxygen free radical scavenging abilities of vitamins $C$ and $E$, and a grape seed proanthocyanidin extract in vitro. Res CommunMol Pathol Pharmacol 95: 179189.

12. Havsteen B (1983) Flavonoids, a class of natural products of high pharmacological potency. Biochem Pharmacol 32: 1141-1148.

13. Leo R, Harold S (2005) Epicatechin for hypertension treatment. Patents.

14. Porter JL, Nowman HR, Foo YL, Wong H (1981) Polymeric procyanidins. $13 C$ N.M.R. studies of Procyanidins. Journal of Chemical Society Perkin Transaction 11982: $1217-1221$.

15. Castilo G, Nguyen B, Choi P, Larsen L, Lormer S, et al. (2003) Isolation, purification and synthesis of procyanidin b2 and uses thereof. Patents.

16. Zhao J, Wang J, Chen Y,Agarwal R (1999) Anti-tumor promoting activity of a polyphenolic fraction isolated from grape seed in the mouse skin two-stage initiation-promotion protocol and identification of procyanidin B5-3'-gallate as the most effective antioxidant constituent. Carcinogenesis 20: 1737-1745. 